\title{
THE IMPORTANCE OF ANTHROPOMETRIC PAREMETERS IN PATIENTS WITH SUBCLINICAL HYPOTHYROIDISM
}

\author{
Mulić Mersiha, ${ }^{1}$ Muminović Suada, ${ }^{2}$ Škrijelj Fadil, ${ }^{3}$ Mulić Mersudin, ${ }^{3}$ Vujošević Snežana ${ }^{4}$ \\ ${ }^{1}$ Faculty of Medicine University of Belgrade, Belgrade, Serbia \\ ${ }^{2}$ Community Health Centre Tutin, Tutin, Serbia \\ ${ }^{3}$ State University of Novi Pazar, Novi Pazar, Serbia \\ ${ }^{4}$ Departmemt of endocrinology, Clinical center of Montenegro, Podgorica, Montenegro
}

Primljen/Received 15. 01. 2018. god.

Abstract: Introduction: The concept of subclinical thyroid disease appeared in the 1980s when sensitive procedures for the measurement of the thyroid-stimulating hormone in the serum were introduced. Subclinical hypothyroidism is defined by the finding of elevated serum TSH concentrations with normal thyroid hormone levels. The incidence of subclinical hypothyroidism with increased cardiovascular risk has not yet been fully clarified.

The aim of the study was to identify anthropometric parameters that may indicate an increased cardiometabolic risk in patients with subclinical hypothyroidism.

Method: The study will include 140 patients aged 18-65, with 105 patients with subclinical hypothyroidism and a control group of 35 healthy, normally nourished subjects without subclinical hypothyroidism. A program of research will be carried out in all patients and it will include: detailed anamnesis and physical examination, anthropometric measurements (weight measurements, body height, waist circumference, hip circumference, body weight mass measurement by the bioelectrical impedance analysis method (\%BFP), calculation of: body mass index (BMI), waist-to-hip circumference ratio $(\mathrm{WC} / \mathrm{HC})$, waist-to-height ratio $(\mathrm{WC} / \mathrm{Ht})$ and laboratory testing (FT3, FT4, TSH).

Results: Examinees with subclinical hypothyroidism had statistically significantly elevated mean TSH values $(6.87+1.34 \mathrm{mIU} / \mathrm{ml})$ compared to TSH euthyroid examinees $(1.9+.88 \mathrm{mIU} / \mathrm{ml})$. The mean age of subjects with subclinical hypothyroidism was $44.15 \pm$ 11.23 years ( $\mathrm{MA}=43$ years), and in subjects without subclinical hypothyroidism, $33.80 \pm 10.60$ years (MA $=33$ years). In relation to the control group (euthyroid patients), patients with subclinical form of hypothyroidism had higher average mean values and statistically
Prihvaćen/Accepted 15. 03. 2018. god.

significantly higher incidence of elevated values: BMI ( $\mathrm{T}$ test $\left.=7.465, \mathrm{p}<0.0001 ; \chi^{2}=35.977, \mathrm{p}<0.0001\right)$, \%BFP $\left(\right.$ T test $=8.594, \mathrm{p}<0.0001 ; \chi^{2}=44.956, \mathrm{p}<$ $0.0001), \mathrm{WC}\left(\mathrm{T}\right.$ test $=6.262, \mathrm{p}<0.0001 ; \chi^{2}=48.865, \mathrm{p}$ $<0.0001$ ), and $\mathrm{WC} / \mathrm{Ht}$ ratio $(\mathrm{T}$ test $=7.372, \mathrm{p}<0.0001$; $\left.\chi^{2}=39.175, \mathrm{p}<0.0001\right)$. The $\mathrm{WC} / \mathrm{HC}$ ratio in the group with subclinical hypothyroidism was higher than in the group without subclinical hypothyroidism, but not statistically significant $\left(\mathrm{T}\right.$ test $=-0.946, \mathrm{p}=\mathrm{ns} ; \chi^{2}=$ $0.622, \mathrm{p}=0$ ).

Conclusion: In the subclinical form of hypothyroidism, changes in the degree of nutrition and body weight can already be recorded, which, among other things, contributes to the development of increased cardiometabolic risk.

Key words: subclinical hypothyroidism, anthropometric parameters, cardiometaolic risk

\section{INTRODUCTION}

Subclinical thyroid dysfunction or "mild" thyroid disease is a common disorder, mainly in middle-aged and elderly people (1).

Subclinical hypothyroidism ( $\mathrm{SH}$ ) is defined by the finding of elevated serum TSH concentrations with the normal values of thyroid hormones $(2,3)$.

Subclinical thyroid disease attracts attention and researchers reaffirm the need for the analysis of the possible meaning of this condition.

There are still controversial opinions about defining, clinical significance, the need for rapid diagnosis and the treatment of sub-clinical thyroid dysfunction (4). It is still an open question whether subclinical thyroid dysfunction can lead to fatal consequences for the 
cardiovascular system by increasing the risk of mortality $(2,3,5-10)$.

Cardiometabolic risk presents a comprehensive risk of developing type 2 diabetes and cardiovascular disease as a result of multiple risk factors. The central type of obesity, dyslipidemia, glycosidic tolerance and hypertension disorder are its main characteristics $(11,12)$.

In this study we proceeded from the assumption that changes in the size and distribution of body weight, which among other things contribute to the development of increased cardiometabolic risk, can be recorded in the subclinical form of hypothyroidism.

The authors assume that the effect of levothyroxine therapy in these patients would be to reduce mortality from cardiovascular diseases $(1,13-20)$.

\section{AIM OF THE STUDY}

The aim of this study is to identify anthropometric parameters that may indicate an increased cardiometabolic risk in patients with subclinical hypothyroidism: BMI, body fat percentage, distribution of body weight (waist circumference, waist-to-hip ratio, waist-to height ratio).

\section{MATERIALS AND METHOD}

The study included 140 patients aged 18-65, out of whom 105 patients had subclinical hypothyroidism and 35 patients were the euthyroid controls.

The study was carried out according to the following protocol:

1. Obtaining history data. History data were obtained by means of structured history questionnaire.

2. Physical examination.

3. Anthropometric measurements. The patients were examined in fasting state (not taking food 12 to $14 \mathrm{~h}$ prior to testing).

a) Measurement of body weight was performed by medical decimal scales with moving weights, with the precision of $0.1 \mathrm{~kg}$.

b) Body height was measured with Martin's anthropometer with the precision of $0.1 \mathrm{~cm}$.

c) Measurement of waist circumference was performed in the standing position at the level of the median distance between the costal arch and the anterior superior iliac spine.

d) BMI was obtained as the quotient of body weight $(\mathrm{kg})$ and body height $(\mathrm{m} 2)$.

e) Measurement of the body fat mass was performed using the bioelectric impedance analysis procedure. Patients were recommended not to eat or drink anything at least four hours before measurement, to avoid physical activity 12 hours before measurement, not to take alcohol for 48 hours before measurement, not to take diuretics seven days before measurement, and to empty their urinary bladder 30 minutes before measurement. The body fat mass measurement was performed with Tanita Body Composition Analyzer BC-418 MA III (Tanita Corporation, MADE IN P.R.C.2004).

Technical characteristics of the appliance: Max $136 \mathrm{~kg}$, delta $=0.1 \mathrm{~kg}, \%$ Body fat increments: $0.5 \%$

4. Laboratory tests: TSH and FT4 were determined by immunochemical method -chemiluminescent procedure including chemiluminescent substrate. The method was automated (IMMULITE® DPC). Reference values: TSH: 0.27-4.20 mIU/ml; FT4: 10-22 pmol/L. Variation coefficient: fT4: $6.20 \%$, TSH: $5.50 \%$. FT3 hormone was measured by enzyme-linked fluorescence assay (ELFA) using miniature VIDAS immunochemical analyzer. Reference values were 4.00-8.30 pmol/L. Variation coefficient: $5.30 \%$.

The study included patients who met all inclusion and had none of exclusion criteria.

Inclusion criteria were as follows:

1. Patients aged 18 to 65 .

Exclusion criteria:

1. Patients with diagnosed diabetes mellitus.

2. Use of medicaments that may interfere with studied parameters (glucocorticoids, iodine preparations, amiodarone, diuretics, lithium, cytostatics, antidepressants, estrogens, androgens).

3. Chronic diseases that may have effect on studied parameters (systemic autoimmune diseases, malignant diseases, chronic renal failure, liver insufficiency, acute coronary syndrome and stroke within the last 6 months).

4. Recent use of radioactive iodine, thyroid surgery and external neck radiation.

5. Pregnancy and breast feeding.

Forming study group: Criterion for patients to be enrolled in the subclinical hypothyroidism group and in the controls was $\mathrm{TSH}>4.2 \mathrm{IU} / \mathrm{mL}$ and $\mathrm{TSH} \leq$ $4.2 \mathrm{UI} / \mathrm{mL}$.

Recommendations by the International Diabetes Federation (IDF) of April 2005 were taken for the definition of abdominal obesity. IDF recommends that the waist circumference threshold for abdominal obesity should be $>=94 \mathrm{~cm}$ in men and $>=80 \mathrm{~cm}$ in women of European descent.

Before starting the statistical analysis, laboratory reports with the results of the patients' analyses were anonymized and all of them were granted identification numbers (for the protection of patient privacy, while patient data were only known to investigators). Electronic data base was created using the SPSS version 20.0. Mean, standard deviation (SD), median, minimum and maximum as well as normal distribution of all studied continuous variables (normal distribution of 
values within the group was analyzed using Kolmogorov-Smirnov test) were determined. To compare the mean values of the continuous variables, we used repeated-measure unifactorial ANOVA and the dependent sample T-test in normal distribution, or alternatively, Mann-Whitney U-test (non-parametric test, alternative to T-test), and Wilcoxon matched pairs test for the outcomes not following normal distribution, as well as $\chi^{2}$ test for the comparison of frequency of categorical (dichotomous) variables. $\mathrm{P}<0.05$ was statistically significant, with a $95 \%$ confidence interval.

\section{RESULTS}

The study included 140 patients aged 18-65, out of whom 105 patients had subclinical hypothyroidism and 35 patients were the euthyroid controls.
Testing the normality of the series (Skewness test), as well as determining the coefficient of variation $(>30 \%$ ), it was shown that the mean TSH value of patients in the group with $\mathrm{SH}$ has a mean value which is statistically significantly higher than in patients without SH (Table 1).

The average age of patients with $\mathrm{SH}$ was $44.15 \pm$ 11.23 years $(\mathrm{MA}=43$ years $)$, and for patients without $\mathrm{SH}$ it was $33.80 \pm 10.60$ years $(\mathrm{MA}=33$ years $)$. The mean age of 105 patients from the experimental group was statistically significantly higher than the mean age in 35 patients from the group without $\mathrm{SH}$ (analyzed using ANOVA test, $\mathrm{p}<0.0001$. (Table 2).

Testing the normality of the series (Skewness test), as well as determining the coefficient of variation $(>$ $30 \%$ ), proved that the following series of parameters that were monitored have a normal distribution (Table 3).

Table 1. Parameters of thyroid status in relation to the presence of SH

\begin{tabular}{|l|c|c|c|c|c|c|c|c|c|c|}
\hline & \multicolumn{3}{|c|}{ With SH } & \multicolumn{3}{c|}{ Without SH } & \multicolumn{2}{c|}{ Variant analysis } & \multicolumn{2}{c|}{ Stud. T test/U test } \\
\cline { 2 - 12 } & Number & $\begin{array}{c}\text { Mean } \\
\text { value }\end{array}$ & SD & Number & $\begin{array}{c}\text { Mean } \\
\text { value }\end{array}$ & SD & F & sig. & $\begin{array}{c}\text { T test } \\
/ U \text { test }\end{array}$ & sig \\
\hline FT3 pmol/L & 105 & 4.98 & 0.86 & 35 & 4.71 & 0.64 & 2.851 & 0.094 & 1.688 & 0.094 \\
\hline FT4: $\mathrm{pmol} / \mathrm{L}$ & 105 & 14.45 & 2.37 & 35 & 14.94 & 2.38 & 1.118 & 0.292 & -1.057 & 0.292 \\
\hline TSH:m IU/ml* & 105 & 6.87 & 1.34 & 35 & 1.9 & 0.88 & 419.612 & $0.0001 * * *$ & 630.00 & $0.0001 * * *$ \\
\hline
\end{tabular}

FT3-free triodothyronine; FT4 - free thyroxine; TSH: thyroid stimulating hormone

Table 2. Mean age in relation to groups and T test

\begin{tabular}{|c|c|c|c|c|c|c|}
\hline & \multicolumn{3}{|c|}{ With SH } & \multicolumn{3}{c|}{ Without SH } \\
\cline { 2 - 7 } & Number & Median & Skewness & Number & Median & Skewness \\
\hline Age & 105 & 43.00 & 0.09 & 35 & 33.00 & 0.49 \\
\hline & number & Mean value & SD & Number & Mean value & SD \\
\hline Age & 105 & 44.15 & 11.23 & 35 & 33.80 & 10.60 \\
\hline & \multicolumn{5}{c|}{ Variant analysis } \\
\hline Age & \multicolumn{5}{c|}{ F $=22.91, \mathrm{p}<0.0001^{* * *}$} \\
\hline Age & \multicolumn{7}{c|}{ Stud. T test $\mathrm{p}<0.0001^{* * *}$} \\
\hline
\end{tabular}

SH: subclinical hypothyroidism

Table 3. Testing the distribution normality, median by group

\begin{tabular}{|l|c|c|c|c|c|c|}
\hline \multirow{2}{*}{} & \multicolumn{3}{|c|}{ With SH } & \multicolumn{3}{c|}{ Without SH } \\
\cline { 2 - 7 } & Number & Median & Skewness & Number & Median & Skewness \\
\hline WC:cm & 105 & 90.00 & 0.34 & 35 & 77.00 & 0.19 \\
\hline HC:cm & 105 & 102.00 & 0.73 & 35 & 89.00 & -0.33 \\
\hline WC/HC & 105 & 0.88 & 0.19 & 35 & 0.88 & 0.18 \\
\hline Ht:cm & 105 & 166.00 & 0.57 & 35 & 170.00 & 1.11 \\
\hline WC/Ht & 105 & 0.54 & 0.31 & 35 & 0.45 & -0.13 \\
\hline BWT:kg & 105 & 80.60 & 0.48 & 35 & 63.80 & 0.47 \\
\hline BMI & 105 & 28.41 & 0.32 & 35 & 22.97 & -0.95 \\
\hline \%BFP & 105 & 38.50 & -0.46 & 35 & 25.50 & -0.16 \\
\hline
\end{tabular}

WC(waist circumference); HC(hip circumference); WC/HC (waist-to-hip ratio); Ht (body height); WC/Ht (waist-to-height ratio); BWT(body weight); BMI (Body Mass Index); \%BFT (\% body fat percentage). 
Table 4. Descriptive statistics of anthropometric parameters in relation to groups

\begin{tabular}{|l|c|c|c|c|c|c|c|c|c|c|}
\hline & \multicolumn{3}{|c|}{ With SH } & \multicolumn{3}{c|}{ Without SH } & \multicolumn{2}{c|}{ Variant analysis } & \multicolumn{2}{c|}{ Stud. T test } \\
\hline & Number & $\begin{array}{c}\text { Mean } \\
\text { value }\end{array}$ & SD & Number & $\begin{array}{c}\text { Mean } \\
\text { value }\end{array}$ & SD & F & sig. & T test & Sig. \\
\hline WC:cm & 105 & 90.88 & 11.53 & 35 & 77.66 & 8.24 & 39.217 & $0.0001^{* * *}$ & 6.262 & $0.0001^{* * *}$ \\
\hline HC:cm & 105 & 103.62 & 11 & 35 & 87.49 & 6.64 & 66.987 & $0.0001^{* * *}$ & 8.185 & $0.0001^{* * *}$ \\
\hline WC/HC & 105 & 0.88 & 0,06 & 35 & 0.89 & 0.06 & 0.895 & 0.346 & -0.946 & 0.346 \\
\hline Ht:cm & 105 & 166.47 & 7.74 & 35 & 171.14 & 8.99 & 8.817 & $0.004^{* *}$ & -2.969 & $0.004^{* *}$ \\
\hline WC/Ht & 105 & 0.55 & 0.07 & 35 & 0.45 & 0.04 & 54.353 & $0.0001^{* * *}$ & 7.372 & $0.0001^{* * *}$ \\
\hline BWT:kg & 105 & 80.18 & 14.26 & 35 & 65.81 & 10.42 & 30,136 & $0.0001^{* * *}$ & 5.490 & $0.0001^{* * *}$ \\
\hline BMI & 105 & 28.89 & 5.02 & 35 & 22.35 & 2.11 & 55,719 & $0.0001^{* * *}$ & 7.465 & $0.0001^{* * *}$ \\
\hline \%BFP & 105 & 37.26 & 7.73 & 35 & 24.56 & 7.07 & 73,856 & $0.0001^{* * *}$ & 8.594 & $0.0001^{* * *}$ \\
\hline
\end{tabular}

WC(waist circumference); HC(hip circumference); WC/HC (waist-to-hip ratio); Ht (body height); WC/Ht (waist-to-height ratio); BWT(body weight); BMI (Body Mass Index); \%BFT (\% body fat percentage).

Table 5. Distribution of selected parameters in relation to reference values and in relation to groups

\begin{tabular}{|c|c|c|c|c|c|c|}
\hline \multicolumn{2}{|c|}{} & \multicolumn{2}{c|}{ With SH } & \multicolumn{2}{c|}{ Without SH } & $\chi^{2}$ \\
\cline { 3 - 7 } \multicolumn{2}{|c|}{} & Number & $\%$ & Number & $\%$ & sign \\
\hline \multirow{2}{*}{ WC } & Normal & 19 & $18.1 \%$ & 29 & $82.9 \%$ & 48.865 \\
\cline { 2 - 7 } & Elevated & 86 & $81.9 \%$ & 6 & $17.1 \%$ & $0.0001^{* * *}$ \\
\hline \multirow{2}{*}{ WC/HC } & Normal & 43 & $41.0 \%$ & 17 & $48.6 \%$ & 0.622 \\
\cline { 2 - 7 } & Elevated & 62 & $59.0 \%$ & 18 & $51.4 \%$ & $0.430 / \mathrm{ns}$ \\
\hline \multirow{2}{*}{ WC/Ht } & Normal up to 0.5 & 25 & $23.8 \%$ & 30 & $85.7 \%$ & 39.175 \\
\cline { 2 - 7 } & Elevated $>0.5$ & 80 & $76.2 \%$ & 5 & $14.3 \%$ & $0.0001^{* * *}$ \\
\hline \multirow{2}{*}{ BMI } & do 25 & 23 & $21.9 \%$ & 35 & $100.0 \%$ & 65.977 \\
\cline { 2 - 7 } & $>25$ & 82 & $78.1 \%$ & 0 & $0.0 \%$ & $0.0001^{* * *}$ \\
\hline \multirow{2}{*}{$\%$ BFP } & Normal & 28 & $26.7 \%$ & 32 & $91.4 \%$ & 44.956 \\
\cline { 2 - 7 } & Elevated & 77 & $73.3 \%$ & 3 & $8.6 \%$ & $0.0001^{* * *}$ \\
\hline
\end{tabular}

WC (waist circumference); HC (hip circumference); WC/HC (waist-to-hip ratio); Ht (body height); WC/Ht (waist-to-height ratio); BWT(body weight); BMI (Body Mass Index); \%BFT (\% body fat percentage).

Table 6. Testing the differences of the selected parameters by groups

\begin{tabular}{|l|c|c|c|c|c|c|c|c|c|}
\hline & $\begin{array}{c}\text { Mann- } \\
\text { Whitney U }\end{array}$ & $\begin{array}{c}\text { Wilcoxon } \\
\text { W }\end{array}$ & $\mathbf{Z}$ & $\begin{array}{c}\text { Asymp. } \\
\text { Sig. }\end{array}$ & $\begin{array}{c}\text { Monte } \\
\text { Carlo Sig }\end{array}$ & $\begin{array}{c}\text { Kruskal } \\
\text { Wallis Test }\end{array}$ & Sig. & $\begin{array}{c}\text { Kolmo } \\
\text { gorov- } \\
\text { Smir.Z }\end{array}$ & Sig. \\
\hline Age & 925.50 & 1555.50 & -4.39 & $\mathbf{0 . 0 0 0}$ & 0.00 & 19.29 & $\mathbf{0 . 0 0 0}$ & 1.95 & $\mathbf{0 . 0 0 1}$ \\
\hline WC:cm & 669.00 & 1299.00 & -5.63 & $\mathbf{0 . 0 0 0}$ & 0.00 & 31.66 & $\mathbf{0 . 0 0 0}$ & 2.49 & $\mathbf{0 . 0 0 0}$ \\
\hline HC:cm & 331.00 & 961.00 & -7.26 & $\mathbf{0 . 0 0 0}$ & 0.00 & 52.63 & $\mathbf{0 . 0 0 0}$ & 3.46 & $\mathbf{0 . 0 0 0}$ \\
\hline WC/HC & 1655.50 & 7220.50 & -0.88 & $\mathbf{0 . 3 8 0}$ & 0.39 & 0.77 & $\mathbf{0 . 3 8 0}$ & 0.68 & $\mathbf{0 . 7 3 9}$ \\
\hline Ht:cm & 1292.50 & 6857.50 & -2.63 & $\mathbf{0 . 0 0 9}$ & 0.01 & 6.90 & $\mathbf{0 . 0 0 9}$ & 1.27 & $\mathbf{0 . 0 8 0}$ \\
\hline WC/Ht & 430.00 & 1060.00 & -6.77 & $\mathbf{0 . 0 0 0}$ & 0.00 & 45.88 & $\mathbf{0 . 0 0 0}$ & 3.32 & $\mathbf{0 . 0 0 0}$ \\
\hline BWT:kg & 782.50 & 1412.50 & -5.08 & $\mathbf{0 . 0 0 0}$ & 0.00 & 25.78 & $\mathbf{0 . 0 0 0}$ & 2.44 & $\mathbf{0 . 0 0 0}$ \\
\hline BMI & 402.00 & 1032.00 & $-6,91$ & $\mathbf{0 . 0 0 0}$ & 0.00 & 47.72 & $\mathbf{0 . 0 0 0}$ & 4.00 & $\mathbf{0 . 0 0 0}$ \\
\hline \%BFP & 447.50 & 1077.50 & -6.69 & $\mathbf{0 . 0 0 0}$ & 0.00 & 44.77 & $\mathbf{0 . 0 0 0}$ & 3.17 & $\mathbf{0 . 0 0 0}$ \\
\hline fT3 pmol/L & 1449.00 & 2079.00 & -1.87 & $\mathbf{0 . 0 6 2}$ & 0.06 & 3.50 & $\mathbf{0 . 0 6 2}$ & 1.42 & $\mathbf{0 . 0 3 6}$ \\
\hline fT4: $\mathrm{pmol} / \mathrm{L}$ & 1619.00 & 7184.00 & -1.05 & $\mathbf{0 . 2 9 3}$ & 0.31 & 1.11 & $\mathbf{0 . 2 9 3}$ & 0.68 & $\mathbf{0 . 7 3 9}$ \\
\hline TSH:mIU/ml & 0.00 & 630.00 & -8.84 & $\mathbf{0 . 0 0 0}$ & 0.00 & 78.19 & $\mathbf{0 . 0 0 0}$ & 5.12 & $\mathbf{0 . 0 0 0}$ \\
\hline
\end{tabular}

WC (waist circumference); HC (hip circumference); WC/HC (waist-to-hip ratio); Ht (body height); WC/Ht (waist-to-height ratio); BWT (body weight); BMI (Body Mass Index); \%BFT (\% body fat percentage); FT3-free triodothyronine; FT4 - free thyroxine; TSH: thyroid stimulating hormone. 
Table 4 lists descriptive statistics of anthropometric parameters in relation to the groups, and the distribution of selected parameters in relation to the reference values and in relation to the groups is shown in Table 5.

Table 6 shows the results of testing of the tested parameters in the experimental group in relation to the control group with nonparametric tests.

In relation to the control group (euthyroid patients), patients with subclinical hypothyroidism had higher mean values and statistically significantly higher incidence of elevated values: BMI, \% BFP, WC, and $\mathrm{WC} / \mathrm{Ht}$ ratio $(\mathrm{p}<0.0001)$. The $\mathrm{WC} / \mathrm{HC}$ ratio in the subclinical hypothyroid group was higher than in the group without subclinical hypothyroidism, but not statistically significant $\left(\mathrm{T}\right.$ test $=-0.946, \mathrm{p}=\mathrm{ns} ; \chi^{2}=0.622$, $\mathrm{p}=0)$.

\section{DISCUSSION}

In this study we found that in patients with $\mathrm{SH}$, in relation to the control group of normally nourished persons without a thyroid gland function disorder, there are changes in the anthropometric parameters, especially in the degree of nutrition, as well as an increase in body weight, which among other things contributes to the development of increased cardiometabolic risk.

The prevalence of subclinical hypothyroidism in adult population is 4 to $8.5 \%(1,21)$. The prevalence increases with age, and in women over 60 years of age it is $20 \%(1,21)$. Annually, 2 to $5 \%$ of patients who have had subclinical hypothyroidism develop clinically expressed hypothyroidism.

The causes of subclinical hypothyroidism may be endogenous (chronic autoimmune thyroiditis, subacute thyroiditis, postpartum thyroiditis), or exogenous (tiroidectomy, radioactive iodine treatment, antithyroid drugs, inadequate thyroid hormone replacement) $(3,22)$.

The presence of hypothyroidism symptoms in patients with subclinical hypothyroidism remains controversial. Based on clinical symptoms, it is difficult to distinguish between a euthyroid person and a person with subclinical hypothyroidism. Many symptoms are non-specific and are related to the severity of the disease, the duration of the disease, the individual sensitivity of peripheral target organs to the deficit of thyroid hormones $(4,23,24)$.

In their study (15), Kong and associates showed that women with subclinical hypothyroidism complained of fatigue (83\%) and weight gain (80\%). 50\% of women had an elevated level of anxiety (25).

A more recent review of the clinical consequences of thyroid function variations within the normal reference range documented that even modest elevations of TSH might have substantial health outcomes, including cardiovascular mortality (26). The results of meta-analyses of Yang et al. demonstrated that $\mathrm{SH}$ was significantly associated with a higher risk of MetS (27).

Metabolic syndrome (MetS) can be defined in different ways, but the central type of obesity, dyslipidemia, glycosidic disorder and hypertension disorder are its main characteristics. These criteria are consistent with the data obtained from the INTERHEART study, which showed that dyslipidemia, hypertension, abdominal obesity and diabetes are among the nine most significant risk factors that account for $90 \%$ of the population risk for myocardial infarction (28).

In 2005, IDF and the American Heart Association/National Heart, Lung and Blood Institute (AHA/NHLBI) (29-31) tried to agree on the criteria of the clinical definition of MetS. However, their recommendations differ in terms of waist circumference.

IDF recommends that the threshold for waist circumference in abdominal obesity should be $>=94 \mathrm{~cm}$ in men and $>=80 \mathrm{~cm}$ in women of European descent; AHA/NHLBI recommend values of $>=102 \mathrm{~cm}$ for men and $>=88 \mathrm{~cm}$ for women.

In our study of 105 patients in the $\mathrm{SH}$ group, the waist circumference was $90.88 \pm 11.53 \mathrm{~cm}$, and in the group without $\mathrm{SH}$ the waist circumference was statistically significantly lower, and it was $77.66 \pm 8.24 \mathrm{~cm}$ (p $<0.0001)$. In the group with SH there were 19 patients (18.1\%) with WC within the reference values, while 86 $(81.9 \%)$ of the patients had elevated values of waist circumference. In the group without SH there were 29 patients $(82.9 \%)$ with WC within the reference values, while $6(17.1 \%)$ of the patients had elevated values of waist circumference $(\mathrm{p}<0.0001)$.

The average value of $\mathrm{HC}$ in patients with $\mathrm{SH}$ was $103.62 \pm 11 \mathrm{~cm}$, and in patients without $\mathrm{SH}$ it was $87.49 \pm 6.64 \mathrm{~cm}(\mathrm{p}<0.0001)$.

The relationship between hip and waist is an index that easily distinguishes two types of obesity from each other, not equally significant in terms of presenting the potential risk of morbidity. If this ratio was higher than 0.9 in women and 1.0 in men, obesity is abdominal (32). When analyzing the $\mathrm{WC} / \mathrm{HC}$ ratio in the group with $\mathrm{SH}$ there were 43 patients $(41 \%)$ with $\mathrm{WC} / \mathrm{HC}$ within the reference values, while $62(59 \%)$ patients had elevated $\mathrm{WC} / \mathrm{HC}$ values. In the group without $\mathrm{SH}$ there were 17 patients $(48.6 \%)$ with $\mathrm{WC} / \mathrm{HC}$ within the reference values, while $18(51.4 \%)$ of the patients had elevated $\mathrm{WC} / \mathrm{HC}$ values $(\mathrm{p}=0.430)$.

The relationship between waist and height is a better indicator of heart disease and diabetes than a body mass index, according to a new study recently presented by Dr Margaret Ashwell (32-37).

In our study, the average value of the $\mathrm{WC} / \mathrm{Ht}$ ratio of patients with $\mathrm{SH}$ was $0.55 \pm 0.07$, and for patients 
without SH it was $0.45 \pm 0.04(\mathrm{p}<0.0001)$. In the $\mathrm{SH}$ group there were 25 patients $(23.8 \%)$ with $\mathrm{WC} / \mathrm{Ht}$ within the reference values, while $80(76.2 \%)$ of patients had elevated $\mathrm{WC} / \mathrm{Ht}$ values. In the group without $\mathrm{SH}$ there were 30 patients $(85.7 \%)$ with $\mathrm{WC} / \mathrm{Ht}$ within the reference values, while $5(14.3 \%)$ of the patients had elevated $\mathrm{WC} / \mathrm{Ht}$ values $(\mathrm{p}<0.0001)$.

According to the criteria of the World Health Organization, the BMI values between 18.5 and $24.9 \mathrm{~kg} / \mathrm{m}^{2}$ corresponded to normal nutrition (38). The values given by IDF correspond to the BMI of about $25 \mathrm{~kg} / \mathrm{m}^{2}$.

The results of this study give an average BMI value in patients with $\mathrm{SH}$ of $28.89 \pm 5.02 \mathrm{~kg} / \mathrm{m}^{2}$ and in patients without SH the BMI is $22.35 \pm 2.11 \mathrm{~kg} / \mathrm{m}^{2}(\mathrm{p}<0.0001)$.

When analyzing the BMI in the group with $\mathrm{SH}, 23$ BMI values (21.9\%) were within the reference values up to 25 , while $82(59 \%)$ of patients had BMI values above 25 . In the group without SH there were 35 patients $(100 \%)$ with BMI within the reference values $(\mathrm{p}<0.0001)$.

Fat tissue plays an important role in MetS pathogenesis, promoting inflammation, hypertension, and dyslipidemia, which all contribute to the development of T2DM, atherosclerosis, and thrombosis. Body weight increment in patients with subclinical hypothyroidism may also contribute to the development of insulin resistance (39-41), which, in addition to the earlier understanding of the causes of increased cardiovascular risk, may have implications in explaining these etiopathogenetic relationships. The role of obesity in the onset of MetS can be seen from the correlation between the rise in the prevalence of MS and obesity in the United States and other countries (42-44).

In our study, the percentage of average fat mass body fat (\% BFT) was statistically significantly higher in patients with SH (37.26) compared to patients without SH $(24.56)(\mathrm{p}<0.0001)$. In the SH group, 28 patients $(26.7 \%)$ were with BFP in reference values, while
77 (73.3\%) patients had elevated\% BFP values. In the group without $\mathrm{SH}$ there were $32(91.4 \%)$ patients with $\%$ BFP within the reference values, while $3(8.6 \%)$ patients had elevated \%BFP values.

In conclusion, we can say that the results of this study suggest that patients with subclinical hypothyroidism have changes in anthropometric parameters, especially in the degree of nutrition, as well as in the increase in body weight, and on the whole, represent a category of people with elevated cardiovascular risk. Timely and precise identification of these parameters in patients with subclinical hypothyroidism opens the possibility of specific therapeutic intervention directed against the reduction of cardiovascular risk.

\section{DECLARATION OF INTEREST}

The autors declare that there are no conflicts of interests
Abbreviations
SH - subclinical hypothyroidism
TSH - thyroid stimulating hormone
FT3 - free triodothyronine
FT4 - free thyroxine
WC - waist circumference
HC - hip circumference
WC/HC - waist-to-hip ratio
Ht - body height
WC/Ht - waist-to-height ratio
BWT — body weight
BMI - Body Mass Index
\%BFT — \% body fat percentage

\section{Licensing}

This work is licensed under a Creative Commons Attribution 4.0 International (CC BY 4.0) License

\title{
Sažetak
}

\section{ZNAČAJ ANTROPOMETRIJSKIH PARAMETARA KOD BOLESNIKA SA SUBKLINIČKOM HIPOTIREOZOM}

\author{
Mulić Mersiha, ${ }^{1}$ Muminović Suada, ${ }^{2}$ Škrijelj Fadil, ${ }^{3}$ Mulić Mersudin, ${ }^{3}$ Vujošević Snežana ${ }^{4}$ \\ Medicinski fakultet u Beogradu, Beograd, Srbija \\ ${ }^{2}$ Dom Zdravlja Tutin, Tutin, Srbija \\ ${ }^{3}$ Državni Univerzitet u Novom Pazaru, Novi Pazar, Srbija \\ ${ }^{4}$ Klinika za endokrinologiju, Klinički centar Crne Gore, Podgorica, Crna Gora
}

Uvod: Koncept o subkliničkoj tiroidnoj bolesti pojavio se osamdesetih godina prošlog veka kada su uvedeni osetljivi postupci za merenje tireostimulišućeg hormona u serumu.

Subklinička hipotireoza definiše se nalazom povišene koncentracije TSH u serumu uz normalne vredno- sti tireoidnih hormona. Udrženost subkliničke hipotireoze sa povećanim kardiovaskularnim rizikom još uvek nije u potpunosti razjašnjen.

Cilj ispitivanja predstavlja identifikaciju antropometriskih parametara koji mogu ukazati na povećan kardiometabolički rizik kod bolesnika sa subkliničkom hipotireozom. 
Metod: Istraživanjem će biti obuhvaćeno 140 bolesnika uzrasta 18-65 godina i to 105 bolesnika sa subkliničkom hipotireozom i kontrolna grupa od 35 zdrava, normalno uhranjena ispitanika bez subkliničke hipotireoze. Kod svih ispitanika biće sproveden program istraživanja koji uključuje: detaljnu anamnezu i fizikalni pregled, antropometriska merenja (merenje telesne mase, telesne visine, obima struka, obima kukova, merenje masne mase tela postupkom bioelektrične impedansne analize (\%BFT). Izračunavanje: indeksa telesne mase (ITM), odnosa obima struk/kuk (OS/OK), odnosa obima struk/telesna visina (OS/TV) i laboratoriska ispitivanja ( FT3, FT4, TSH).

Rezultati: Ispitanici sa subkliničkom hipotireozom imali su statistučki značajno povišene prosečne vrednosti TSH $(6.87 \pm 1.34 \mathrm{mIU} / \mathrm{ml})$ u odnosu na eutiroidne ispitanike TSH ( $1.9 \pm 0.88 \mathrm{mIU} / \mathrm{ml})$. Prosečna starost ispitanika sa subkliničkom hipotireozom bila je $44,15 \pm 11,23$ godina ( $M d=43$ god.), a kod ispitanika

\section{REFERENCES}

1. Canaris GJ, Manowitz NR, Mayor G, Ridgway EC. The Colorado Thyroid Disease prevalence study. Arch Intern Med. 2000; 160(4): 526-34.

2. Gharib H, Tuttle RM, Baskin HJ, Fish LH, Singer PA, McDermott MT. Subclinical thyroid dysfunction: a joint statement on management from the American Association of Clinical Endocrinologists, the American Thyroid Association, and the Endocrine Society. J Clin Endocrinol Metab. 2005; 90(1): 581-5; discussion 586-7.

3. Cooper DS, Biondi B. Subclinical thyroid disease. Lancet. 2012; 379(9821): 1142-54.

4. Biondi B, Cooper DS. The clinical significance of subclinical thyroid dysfunction. Endocr Rev 2008; 29(1): 76-131.

5. Duggal J, Singh S, Barsano CP, Arora R. Cardiovascular risk with subclinical hyïrthyroidism and hypothyroidism: pathophysiology and management. Cardiometab Syndr. 2007; 2(3): 198-206.

6. Razvi S, Shakoor A, Vanderpump M, Weaver JU, Pearce SH. The influence of age on the relationship between subclinical hypothyroidism and ischemic heart disease: a metaanalysis. J Clin Endocrinol Metab. 2008; 93(8): 2998-3007.

7. Neves C, Alves M, Medina JL, Delgado JL. Thyroid diseases, dyslipidemia and cardiovascular pathology. Rev Port Cardiol. 2008; 27(10): 1211-36.

8. Razvi S, Weaver JU, Vanderpump MP, Pearce SH. The incidence of ischemic heart disease and mortality in people with subclinical. Subclinical hypothyroidism: reanalysis of the Whickham Survey cohort. J Clin Endocrinol Metab. 2010; 95(4): 1734-40.

9. Rodondi N, den Elzen WP, Bauer DC, Cappola AR, Razvi S, Walsh JP, et al. Subclinical hypothyroidism and the risk of coronary heart disease and mortality. Thyroid Studies Collaboration. JAMA. 2010; 304(12): 1365-74.

10. McQuade C, Skugor M., Brennan DM, Hoar B, Stevenson C, Hoogwerf BJ. Hypothyroidism and moderate subcli- bez subkliničke hipotireoze bila je 33,80 $\pm 10,60$ godina $(\mathrm{Md}=33$ god.). U odnosu na kontrolnu grupu (eutiroidni pacijenti), ispitanici sa subkliničkom formom hipotireoze imali su više prosečne srednje vrednosti i statistički značajno veću učestalost povišenih vrednosti: ITM $\left(\mathrm{T}\right.$ test $=7,465, \mathrm{p}<0,0001 ; \chi^{2}=35,977, \mathrm{p}<$ $0,0001), \%$ BFT $\left(\right.$ T test $=8,594, \mathrm{p}<0,0001 ; \chi^{2}=44,956$, $\mathrm{p}<0,0001)$, OS $\left(\mathrm{T}\right.$ test $=6,262, \mathrm{p}<0,0001 ; \chi^{2}=48,865$, $\mathrm{p}<0,0001$ ), i odnosa OS/TV (Ttest $=7,372, \mathrm{p}<0,0001$; $\left.\chi^{2}=39,175, \mathrm{p}<0,0001\right)$. Odnos OS/OK u grupi sa subkliničkom hipotireozom bio je viši nego u grupi bez subkliničke hipotireoze, ali ne i statistički značajno (T test $=-0,946, p=n s ; \chi^{2}=0,622, p=0$ ).

Zaključak: Već u subkliničkoj formi hipotireoze mogu se evidentirati promene u stepemu uhranjenosti i veličini masne mase tela, koja između ostalog, doprinosi nastanku povećanog kardiometaboličkog rizika.

Ključne reči: subklinička hipotireoza, antropometriski parametri, kardiometabolički rizik.

nical hypothyroidism are associated with increased all-cause mortality independent of coronary heart disease risk factors: a PreCIS database study. Thyroid. 2011; 21(8): 837-43.

11. Alberti KG, Eckel RH, Grundy SM, Zimmet PZ, Cleeman JI, Donato KA et al. Harmonizing the metabolic syndrome: a joint interim statement of the International Diabetes Federation Task Force on Epidemiology and Prevention; National Heart, Lung, and Blood Institute; American Heart Association; World Heart Federation; International Atherosclerosis Society; and International Association for the Study of Obesity. Circulation 2009; 120(16): 1640-5.

12. Framingham Study Risk Score Profiles. Framingham Heart Study. www.framinghamheartstudy.org/risk/index.html. Accessed December 5, 2012.

13. Cooper DS. Clinikal practice.subclinical hipothyroidism. N Engl J Med. 2001; 345(4): 260-5.

14. Meier C, Staub JJ, Roth CB. Guglielmetti M, Kunz M, Miserez AR et al. TSH-controlled L-thyroxine therapy reduces cholesterol levels and clinical symptoms in subclinical hypothyroidism: a double-blind, placebo-controlled trial (Basel Thyroid Study). J Clin Endocrinol Metab. 2001; 86(10): 4860-6.

15. Kong WM, Sheikh MH, Lumb PJ, Naoumova RP, Freedman DB,Crook M, et al. A 6-month randomized trial of thyroxine treatment in women with mild subclinical hypothyroidism. Am J Med. 2002; 112(5): 348-54.

16. Adrees M, Gibney J, El-Saeity N, Boran G. Effects of 18 months of L-T4 replacement in women with subclinical hypothyroidism. Clin Endocrinol (Oxf). 2009; 71(2): 298-303.

17. Lioudaki E, Mavroeidi NG, Mikhailidis DP, Ganotakis ES. Subclinical hypothyroidism and vascular risk: an update. Hormones. 2013; 12(4): 495-506.

18. Madathil A, Hollingsworth KG, Blamire AM, Razvi S, Newton JL, Taylor R, et al. Levothyroxine improves abnormal cardiac bioenergetics in subclinical hypothyroidism: a cardiac magnetic resonance spectroscopic study. J Clin Endocrinol Metab. 2015; 100(4): E607-10. 
19. Javed Z, Sathyapalan T. Levothyroxine treatment of mild subclinical hypothyroidism: a review of potential risks and benefits. Ther Adv. Endocrinol Metab. 2016; 7(1): 12-23.

20. Mulić M, Halo O, Škrijelj F, Mulić B. Beneficial effects of levothyroxine in the treatment of subclinical hypothyroidism. Sanamed. 2016; 11(3): 203-9.

21. Hollowell JG, Staehling NW, Flanders WD, Hannon WH, Gunter EW, Spencer CA et al. Serum TSH, T4, and thyroid antibodies in the Unated States population (1988 to 1994): National Health and Nutrition Examination Survey (NHANES III). J Clin Endocrinol Metab. 2002; 87(2): 489-99.

22. Karmisholt J, Andersen S, Laurberg PA. Variation in thyroid function in subclinical hypothyroidism: importance of clinical follow-up and therapy. Eur J Endocrinol. 2011; 164(3): 317-23.

23. Bianchi GP, Zaccheroni V, Solaroli E, Vescini F, Cerutti R, Zoli M, et al. Health-related quality of life in patients with thyroid disorders. Qual Life Res. 2004; 13(1): 45-54.

24. Grabe HJ, Volzke H, Ludemann J, Wolff B, Schwahn C, John U, et al. Mental and physical complaints in thyroid disorders in the general population. Acta Psychiatr Scand. 2005; 112(4): 286-293.

25. Sait Gonen M, Kisakol G, Savas Cilli A, Dikbas O, Gungor K, Inal A, et al. Assessment of anxiety in subclinical thyroid disorders. Endocr J. 2004; 51(3): 311-15.

26. Taylor PN, Razvi S, Pearce SH, Dayan CM. Clinical review: a review of the clinical consequences of variation in thyroid function within the reference range. J Clin Endocrinol Metab. 2013; 98(9): 3562-71.

27. Yang L, Lv X, Yue F, Wei D, Liu W, Zhang T. Subclinical hypothyroidism and the risk of metabolic syndrome: a meta-analysis of observational studies. Endocr research. 2016; 41 (2) : 158-65.

28. Yusuf S, Hawken S, Ounpuu S, Dans T, Avezum A, Lanas $\mathrm{F}$ et al. Effect of potentially modifi able risk factors associated with myocardial infarction in 52 countries (The INTERHEART study): case-controle study. Lancet. 2004; 364(9438): 937-52.

29. Alberti KG, Zimmet P, Shaw J; IDF Epidemiology Task Force Consensus Group. The metabolic syndrome a new worldwide definition. Lancet. 2005; 366(9491): 1059-62.

30. The IDF consensus worldwide definition of the metabolic syndrome. Avaible from http: //www.idf.org

31. Clinical guidelines on the identification, evaluation, and treatment of overweight and obesity adults: the evidence report (published correction appears in Obes Res. 1988; 6:464). National Institutes of Health. Obes Res. 1988; 6(suppl 2): 51S-209S.

\section{Correspondence to/Autor za korespondenciju}

Mersiha Mulić, student

Faculty of Medicine University of Belgrade, Belgrade

"Sutjeska" C/11. 36300, Novi Pazar, Serbia

Phone: + 38163661373

e-mail: emmulic@open.telekom.rs
32. Ashwell, M, Gibson, S. Waist to height ratio as an indicator of 'early health risk': simpler and more predictive than using a žmatrix' based on BMI and waist circumference. BMJ Open.2016; 6(3): e010159.

33. Gibson S, Ashwell M. Non-overweight 'apples' have higher cardiometabolic risk factors than overweight žpears': waist-to-height ratio is a better screening tool than BMI for blood levels of cholesterol and glycated haemoglobin. Obesity Facts. 2016. 8 (Suppl 1): 139.

34. Ashwell M, Gibson S. A proposal for a primary screening tool: 'Keep your waist circumference to less than half your height'. BMC Med. 2014; 12(1): 207.

35. Ashwell M, Mayhwe, Richardson J, Rickayzen B. Waist-to-height ratio is more predictive of years of life lost than body mass index. PloS one. 2014; 9(9): e103483.

36. Ashwell M, Gunn P, Gibson S: Waist-to-height ratio is a better screening tool than waist circumference and BMI for adult cardiometabolic risk factors: systematic review and meta-analysis. Obes Rev. 2012; 13(3): 275-86.

37. Ashwell M. Plea for simplicity: use of waist-to-height ratio as a primary screening tool to assess cardiometabolic risk Clin Obes. 2012; 2(1-2): 3-5.

38. World Health Organization. Obesity: preventing and maniging the global epidemic. Report of WHO consultation. WHO Tech Rep Ser. 2000; 894: 1-253.

39. Dietlein M, Kahaly G, Kobe C, Schmidt M, Derwahl $\mathrm{KM}$, Schicha H. [Obesity, energy regulation and thyroid function: is borderline elevated TSH-level the cause or secondary phenomenon of obesity] [Article in German] Nuklearmedizin. 2008; 47(5): 181-7.

40. Grundy SM, Adams-Huet B, Vega GL. Variable contributions of fat content and distribution to metabolic syndrome risk factors. Metab Syndr Relat Disord. 2008; 6(4): 281-8.

41. Ginter E, Simko V. Adult obesity at the beginning of the 21st century: epidemiology, pathophysiology and health risk. Bratisl Lek Listy. 2008; 109(5): 224-30.

42. Cruz M, Weigensberg MJ, Huang TT, Ball G, Shaibi GQ, Goran MI. The metabolic syndrome in overweight Hispanic youth and the role of insulin sensitivity. J Clin Endocrinol Metab. 2004; 89(1): 108-13.

43. Després JP, Lemieux I, Bergeron J, Pibarot P, Mathieu $\mathrm{P}$, Larose $\mathrm{E}$ et al. Abdominal obesity and the metabolic syndrome: contribution to global cardiometabolic risk. Arterioscler Thromb Vasc Biol. 2008; 28(6): 1039-49.

44. Veigas MN, Dharmalingam M., Marcus R.Sh. Oxidative stress in obesity and metabolic syndrome in Indians. Journal of Medical Biochemistry.2011; 30 (2): 115-20. 